\title{
Esl Teacher's Knowledge and Readiness on the Implementation of School-Based Assessment (SBA) in Malaysian Primary School
}

\author{
Alexandra Joachim, Harwati Hashim* \\ Faculty of Education, Universiti Kebangsaan Malaysia, Selangor, Malaysia \\ Email: ^harwati@ukm.edu.my
}

How to cite this paper: Joachim, A., \& Hashim, H. (2021). Esl Teacher's Knowledge and Readiness on the Implementation of School-Based Assessment (SBA) in Malaysian Primary School. Creative Education, 12, 1066-1078.

https://doi.org/10.4236/ce.2021.125079

Received: April 6, 2021

Accepted: May 24, 2021

Published: May 27, 2021

Copyright (c) 2021 by author(s) and Scientific Research Publishing Inc. This work is licensed under the Creative Commons Attribution International License (CC BY 4.0).

http://creativecommons.org/licenses/by/4.0/

\begin{abstract}
In line with the Malaysian education transformation effort to keep up with the current nation needs, a new assessment approach has been implemented on early 2011 namely the school-based assessment or widely known as SBA. Nevertheless, after few years of its implementation, the SBA has caused rippled among educational stakeholders especially the educators. Hence, the purpose of this paper is to identify the English as a Second Language (ESL) teachers' knowledge and readiness in regard to SBA in Sabah primary schools. A survey was conducted to 100 ESL primary school teachers in one of the states in Malaysia, Sabah. The data were collected using questionnaire and then analysed using descriptive analysis. Based on the findings, majority of the respondents are highly knowledgeable in regards to SBA implementation in English class. Similarly, the findings also indicated that majority of the respondents show positive level of readiness to implement SBA for English class in primary schools. Results of this study are able to give relevant picture to policy makers and Malaysian Ministry of Education on the current states of ESL teachers' knowledge and readiness in regards to SBA implementation after being introduced in 2011.
\end{abstract}

\section{Keywords}

School-Based Assessment (SBA), Pedagogical Content Knowledge (PCK), ESL Teachers' Readiness, ESL Teachers' Knowledge, English KSSR

\section{Introduction}

Education systems around the world are going through transformation in order to keep up with the rapid globalization (Ghazali, 2017). Several countries, such as Australia, Hong Kong, Korea, New Zealand, Finland, Greece, Portuguese, 
United Kingdom and Ireland had implemented SBA for many years (Chew \& Muhamad, 2017; Berry, 2011; Majid, 2011). Sweden for example has integrated the concept $\mathrm{d}$ assessment as a positive tool for learning and one of key elements in teaching and learning process (Berry, 2011). Similarly, assessment in Hong Kong has moved from norm-referenced to standard-referenced assessment starting in year 2007 (Yan, 2014; Cheng et al., 2011). In another word, most countries had opted curriculum such as critical thinking, cooperation and problem solving (Berry, 2011).

Previously, assessment in Malaysian schools has been rather centralized and summative in nature (Fook \& Sidhu, 2006). The Malaysian Examination Syndicate (MES) was responsible to prepare the exam papers, administer the exams during examination weeks and marking the exam papers. In short, the assessment system in Malaysia is under close monitoring of MES. Unfortunately, the Ministry of Education (MoE) concluded that the previous assessment system was impractical and put too much pressure on students. Hashim et al. (2013) stated that the previous exam-oriented assessment failed to propel students' true competence. Similarly, Stiggins (2005) affirmed that placing high importance on public examination as the core assessment in education could negatively affecting the pupils' emotional strength which can be a hindrance for the pupils to breakthrough in their learning. Overall, the previous education system especially the assessment procedure might be suitable for students' need then. However, in correspondent with the rapid pace of globalization around the world, a huge makeover for the education system should be executed to suit the ever-changing needs of the $21^{\text {st }}$ century generation. Therefore, in line with the Master Development Plan of Education in 2010, the MoE has overhauled the education system and a new curriculum was implemented called Standard Curriculum for Primary Schools (KSSR acronym in Malay) (MoE, 2010). The transformation aims to review and improve the previous curriculum hence ensuring that the new generation of students received most relevant knowledge, skills and values to embrace the challenges of the $21^{\text {st }}$ century (Ministry of Education, 2013). Subsequently, a new type of assessment approach has been integrated into the assessment system in 2011 which is the School-Based Assessment (SBA). In general, SBA can be defined as one of assessment approach that interconnected with teaching and learning process (Raman \& Yamat, 2014). It is continuous cycle and allows teachers to give immediate constructive feedback to pupils (Raman \& Yamat, 2014). Fook and Sidhu (2006) further define SBA as a course of monitoring, evaluating and executing ideas in order to overcome any issues of the school. Meanwhile, Chew and Muhamad (2017) explained that the assessments in SBA should be designed, build, managed, checked, recorded and reported by the assigned school teachers. As opposed to previous assessment system, SBA supposedly giving more empowerment to teachers in assessing their pupils holistically. Hence, teachers' knowledge and readiness for SBA are pivotal in ensuring the success of SBA in schools. This paper aims to probe into ESL teachers' knowledge and readiness for SBA since its implementation in 2011 and its revi- 
sion in 2017.

During the infancy stage of KSSR implementation, it met with mixed-responses from teachers, consequently a circular of the revised KSSR was released in 2014 to ease the tensions among teachers. After being fully implemented in 2016, the KSSR was revised. The revised KSSR then put into implementation in stages, starting on 2017 batch of Year 1 pupils. The revision for KSSR is to strengthen, improve and to ensure that the curriculum is relevant to the present needs (Kiong et al., 2017). Additionally, it is also evidence that constant research and study on the current education system in Malaysia is needed as it could provide relevant information to educational stakeholders. As a matter of fact, some countries such as Finland, New Zealand, Australia and Hong Kong started to integrate SBA way earlier than Malaysia and despite their years of experiences, vast number of researches have been carried out in order to investigate the relevant aspects of the SBA (Majid, 2011). Henceforth, with the constant change in education field, it is only imperative for SBA to be evaluated from time to time (Talib et al., 2014; Majid, 2011).

Unfortunately, issues regarding the new curriculum have plagued the education field in early stage of its implementation especially regarding the teachers' readiness on the implementation of SBA (Majid, 2011; Hashim et al., 2013; Othman et al., 2013). Hashim et al. (2013) conducted interview to teachers in school and stated that lack of information and training on SBA prior to its implementation hinders them to fully applying SBA in schools. Talib et al. (2014) documented that teachers selected for SBA national level training undergone a week of training, while teachers who went for state level and district level SBA training had undergone mostly three days training. Meanwhile, school level SBA training usually is held for one day or at least one hour. Unfortunately, the "cascading training model" used by the MoE to train teachers on SBA is proved to be futile since the information has been watered down along the way (John, 2018). Therefore, when teachers did not receive appropriate input training on the SBA implementation, they will not be knowledgeable enough to conduct SBA on their pupils (Hashim et al., 2013). Subsequently, teachers as the key element in realizing SBA may complaint of not having sufficient pedagogical knowledge of SBA and their readiness to implement SBA in schools are low. Hence, research on teachers' current knowledge and readiness of SBA implementation would be highly relevant as it could help improve the assessment quality in Malaysian education system.

Another arising problem regarding SBA is teachers claiming that SBA has undoubtedly increased teachers' workload as teachers were burdened with endless paperwork and documentation (Talib et al., 2014). SBA approach supposedly gives teachers more empowerment to assess their pupils which resulting teachers' accountability on the validity and reliability of the pupils' assessment. Consequently, it has become teachers' responsibility to ensure that pupils' individual evidence of learning and records are systematically recorded throughout their schooling years. Therefore, teachers are more involved in the pupils' as- 
sessment as compared to before. Unfortunately, Hashim et al. (2013) stated that with the introduction of new assessment approach, teachers are expected to handle additional assignments in terms of clerical works in addition to their teaching responsibility. These additional workloads had caused continuous assessment which is one of the key elements in SBA, to be a challenge for teachers. SBA highlight the use of assessment as positive tools in assisting pupils' learning process by reflection and close monitoring of their on learning progress through actively being involve during the assessment process (Mansor et al., 2013). Thus if teachers failed to integrated SBA effectively, pupils will not get maximum benefit from the SBA approach in schools.

Previously, teachers' responsibilities are mainly imparting knowledge to pupils and making them ready for examination which executed by the MES. With the integration of SBA into the new curriculum, teachers' roles are increasing as they are responsible in selecting, designing and administering the assessment instrument to pupils while making sure it is being done continuously and systematically recorded. This factor could cause teachers to have negative perception on the SBA in schools which will result in their readiness to implement SBA in schools. Based on these arguments, this paper aims to investigate into the integration of SBA in Malaysian primary schools. The study will be focusing on examining ESL teachers' level of knowledge with regards to SBA and their level of readiness in implementing the SBA. ESL teachers were chosen as the focus of the study as English subject has been one of the compulsories passing subject in Malaysian education system.

\section{Literature Review}

\subsection{School-Based Assessment (SBA) in English Standard Curriculum for Primary Schools (KSSR): Revisit}

SBA is one of the vital components in the current Malaysian curriculum, KSSR (Mansor et al., 2013). In general, the new assessment approach let teachers to assess pupils based on four components namely school assessment, psychometric assessment, physical activity assessment as well as sport and co-curriculum activities (Mansor et al., 2013). Assessing pupils in four dimensions should help teachers to ensure that the assessment done holistically. Through SBA, pupils are assessed as individuals based on their ability, talent, skills and potential (Chew \& Muhamad, 2017). Pupils will be assessed based on evidence markers on certain performance standard starting from Band 1 which is the lowest to Band 6 which is the highest (Othman et al., 2013). Furthermore, the Malaysian Examination Syndicate (MES) has listed the different types of formative assessments in line with SBA. For example, teachers could use different assessment strategies namely portfolio, project-based learning, worksheets, observation, checklists and pop quizzes (MES, 2012). The results of this formative assessment supposedly could help teachers to collect information on the pupils' current learning growth and development. Based on the date collected, teachers may want to make changes in 
their approaches to propel pupils' potential. Finally, pupils will be assessed using summative assessment which is usually in the form of year-end examination administered by schools or MES at the end of schooling year.

Based on the current revised KSSR, the English language curriculum is divided into 5 modules. These modules are the 5 elements in the Malaysian English curriculum namely the Listening, Speaking, Reading, Writing and Language Arts. Each module consists of separate content standard, learning standard and band or performance standards. John (2018) explained in details the three key terms in the English KSSR. The content standard specifies the essential knowledge, skills and understanding that must be acquired by the end of 6 years of schooling. Meanwhile the learning standard is the specific skills and knowledge that need to be acquired by the pupils to fulfil the learning standard by year to year basis from year 1 to year 6 . Finally, the performance standard is the specified criteria and descriptors of each of the learning standards. Its main purpose is for ESL teachers to refer to while doing the assessment on pupils. In short, it serves as a guidance for ESL teachers to gauge the pupils' level of understanding and growth. Based on the result of the assessment, ESL teachers may want to modify their teaching approaches to suit the pupils' learning better. On the other hand, ESL teachers can assess the pupils using observation, checklist and short interview with the pupils to gauge their level of learning growth based on the performance standards. As for recording and reporting purposes, ESL teachers may use checklist and field notes. It is highly crucial to note that through SBA approach, the assessment should be on-going and continuous as teachers may want to modify their assessment approach and instruments to enhance the pupils' learning outcomes.

Previously, ESL teachers are given small authority on assessing their pupils and due to over-reliance on the norm-reference of high-stakes examination, teaching and learning activities in the classroom were very much exam oriented. Therefore, through SBA, teachers are given larger authority in selecting types of classroom assessment to help the pupils in their learning. Based on the discussion of the SBA approach in the current Malaysian English KSSR it is crystal clear that ESL teachers' skills in mastery of assessment are more crucial than before. In short, all ESL teachers must be well versed and knowledgeable in different types of assessment in order to implement the SBA successfully.

\subsection{ESL Teachers' Pedagogical Content Knowledge (PCK)}

The template is used to format your paper and style the text. All margins, column widths, line spaces, and text fonts are prescribed; please do not alter them. You may note peculiarities. For example, the head margin in this template measures proportionately more than is customary. This measurement and others are deliberate, using specifications that anticipate your paper as one part of the entire journals, and not as an independent document. Please do not revise any of the current designations. 
Shulman (1987) proposed the idea that teachers must have the mastery of knowledge in order to teach pupils. He introduced a knowledge framework that contains two distinct knowledge domains: contain knowledge and pedagogical knowledge. This framework is widely known as Pedagogical Content Knowledge (PCK) and it has been popular among educators. Shulman (1987) described PCK as "that special amalgam of content and pedagogy that is uniquely the province of teachers, their own special form of professional understanding (pg 8). He further explains PCK as a combination of both content knowledge (CK) and pedagogy knowledge (PK) to produce understanding of particular subject matters and how to present it for instruction. In essence, PCK is the combination of content and pedagogy knowledge to understand something and the ability to present it for instruction. Shulman (1987) added that it is insufficient for teachers to focus on either one of the knowledge domains. According to him the key to distinguishing the knowledge base of teaching rested at the intersection of content and pedagogical knowledge. Succinctly, Shulman defines content knowledge as the knowledge of representation on subject matter, meanwhile pedagogical knowledge is the teaching strategies and knowledge of students' conception of the subject matters.

Van Driel and Berry (2012) agree that PCK is a dynamic knowledge framework as it responsive to the context of teachers' work. Troyan et al. (2017) further explain that PCK framework for teachers can be elaborated as the teachers' ability to deliver their content knowledge of language into practice or instruction so that pupils will be able to learn. Therefore, PCK in context with this paper is referring to the ESL teachers' knowledge of SBA and readiness to implement the SBA in primary schools. Khatab (2012) argues that without well-developed content knowledge and pedagogical content knowledge, teachers might be less likely to be able to use assessment data contingently. Based on this paper, the content knowledge of ESL teachers is referring to the ESL teachers' mastery of SBA approach in the English KSSR, while the pedagogical knowledge is the ESL teachers' practices or instructions in the classroom. To ensure the success of SBA, it is important for teachers to possess these two knowledge domains in balanced. The following Figure 1 shows schematic diagram of Shulman's PCK framework in context with this paper.

\subsection{ESL Teachers' Knowledge and Readiness of SBA}

Fook and Sidhu (2006) and McMillan (2000) suggest that teachers with insufficient assessment knowledge will inevitably failed in assisting their pupils' learning progress. Chew and Muhamad (2017) further agree that teachers' skills or knowledge in implementing the SBA is highly significant as it can make or break the effectiveness of teaching and learning in classroom therefore risk the success of SBA implementation in Malaysian primary schools. According to McMillan (2000), teachers are able to integrate assessment in schools better when their knowledge of assessment is high. Therefore, in order to successfully implement 


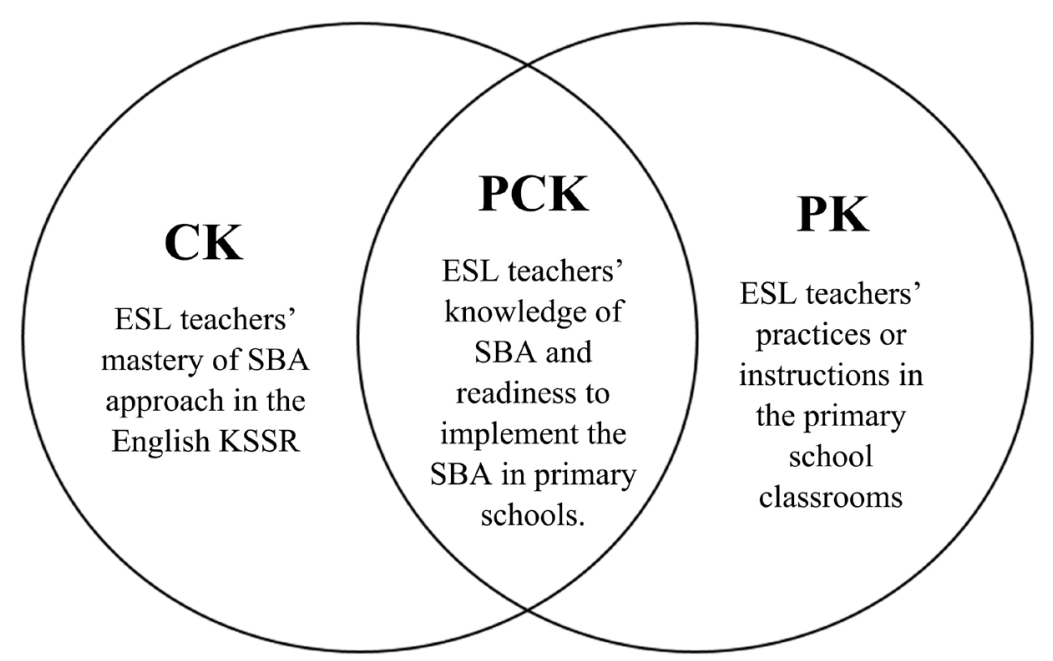

Figure 1. Shulman's pedagogical content knowledge (PCK) framework.

the SBA, teachers should arm themselves with mastery of different types of assessment so that assessment can be done more holistically for pupils during their learning process.

According to Fook and Sidhu (2006), while some are enthusiastically in favour of the change in the Malaysian education assessment approach, there are others who are still sceptical. Chew and Muhamad (2017) state that criticisms from several parties regarding faults in SBA are still heard of even after its $6^{\text {th }}$ years of implementation in Malaysian primary schools. Furthermore, Talib et al. (2014) explain that the shift in the Malaysian assessment system had attracted unpleasant reactions from the teachers all over Malaysia. Reasons for these complaints from teachers might be because of their level of knowledge and skills to implement SBA are still not up to satisfactory level. Cheah (2010) on the other hand, found that teachers' attitude is one of the biggest challenges in conducting SBA. According to Brown, the study of ESL teachers' perceptions of assessment is important because ESL teachers' perceptions influence strongly on how they teach in ESL classrooms. Hence, ESL teachers' perceptions towards SBA play big roles in determining their readiness on implementation of SBA.

Overall, the SBA approach in Malaysia current curriculum is a major shift from the centralized assessment approach in the past. In the age of 4IR where $21^{\text {st }}$ century skills are much demanded; it is only imperative that the government join the race of education reforms all over the world. In order to compete with other developed countries, the MoE must do its part to ensure that the SBA approach in the present education system is being assessed periodically for it to serve the main purpose. Furthermore, Malaysia has a long tradition of having norm-referenced assessment where the teaching and learning is geared towards the high-stakes final examination. The introduction of SBA has caused rippled among many groups of communities. Hence, this paper aims to implore more on the ESL teachers' knowledge of SBA and their readiness in the implementation of SBA as such study is considered relevant and essential as it could provide 
a significant picture of current ESL teachers' knowledge and readiness on the implementation of SBA to scholars and policy makers.

\section{Methodology}

\subsection{Research Design}

To accomplish the purposes of this study, a quantitative research design was used to identify ESL teachers' knowledge and their readiness to implement the SBA in Sabah primary schools. A descriptive cross-sectional survey was carried out in span of 1 month through questionnaire. Kumarsir and Shah (2020) stated that a cross-sectional survey collects information from the samples about a particular topic at a single period of time and this design allow the researcher to investigate current attitudes or practices of targeted population. Furthermore, according to Ponto (2015) and Creswell (2014), survey is one of popular research design among researchers as data collected through survey, able to provide character description of large sample in relatively short amount of time.

\subsection{Research Sample}

Etikan et al. (2016) state that purposive sampling allows researchers to deliberately select the sample based on the qualities that had been decided beforehand. In essence, the sample was deliberately selected following requirements of the subject matter in particular research. Therefore, this study opts to use purposive sampling method as a sampling procedure. The actual population of primary school ESL teachers in Malaysia is fairly large thus this study narrowed down to one state which is Sabah. Hence, to meet the purpose of this research, 100 primary ESL primary teachers (23 male and 77 female) had participated in this research. About $69 \%$ of the participants are novice teacher with $0-5$ years in teaching experience while only $10 \%$ of the participants 20 years and above of teaching experience. On the other hand, $70 \%$ of the participants admitted that they had attended any kind of seminar or workshop about SBA either in school or outside of school. However, $30 \%$ of the participants stated that they never attended any seminar or workshop on SBA. This number is quite concerning as all Malaysian teachers should had attended SBA seminar or workshop at least once after 9 years of being implemented in Malaysia education system.

\subsection{Research Instrument}

An online questionnaire was developed using the Google Form. Online instrument would allow outreach for a wider range of respondents throughout of the state as it can be easily distributed to the targeted respondent using link shared in different sharing platforms. The instrument consists of multiple-choice questions and Likert-scale items. There are 26 questions divided into 3 sections. The questionnaire was adapted from Veloo et al. (2015) in their study titled "Teachers' Knowledge and Readiness towards Implementation of School Based Assessment in Secondary Schools". The first section intents to gather demographic 
details of the respondents. There are 3 multiple questions in the first section. The second section contains 11 questions to elicit respondents' level of knowledge of SBA and the following section contains 12 questions intends to collect data on the respondents' readiness on the implementation of SBA. The perception of the respondents was measured by using the Likert Scale. The four-point Likert scale are ranged at $1=$ strongly disagree, $2=$ disagree, $3=$ agree and $4=$ strongly agree. A pilot test was conducted before the actual study and a total 33 participants had answered to the questionnaire to identify the clarity of wording and item structures. As a result, only one item was restructured due to ambiguity in statement. Data were then tested for reliability using Cronbach's alpha through SPSS. According to Ursachi et al., (2015) Cronbach's alpha values of 0.60 to 0.95 indicate an acceptable level of reliability. The coefficient values according to construct are presented in Table 1.

The data collected through online questionnaire were exported to Statistical Package for Social Science (SPSS) to analyse the outcomes of the study. The finding of the data then analysed using descriptive analysis.

\section{Findings}

The survey instruments were intended to study the ESL teachers' level of knowledge of SBA and their level of readiness to implement the SBA. The total mean score for each section based on constructs is tabulated in Table 2 .

Based on Table 2, majority of the respondents were knowledgeable $(\mathrm{M}=3.37$, $\mathrm{SD}=0.45)$ in regards to SBA implementation. On the other hand, the finding also shows that majority of the respondents possesses high level of readiness ( $M$ $=3.27, \mathrm{SD}=0.37)$ on the SBA implementation in primary schools.

Data presented on Table 3 shows that majority of the respondents admitted that they had clear understanding $(\mathrm{M}=3.38, \mathrm{SD}=0.58)$ of how to assess their pupils based on the Performance Level descriptors in the DSKP. Unfortunately, most of the respondents show concerns with their knowledge to select different assessment strategies $(\mathrm{M}=3.18, \mathrm{SD}=0.57)$ to improve their pupils' higher order thinking skills through SBA. Nevertheless, the total means score is still considered high though it was the lowest means score in section 2 of the survey.

Based on Table 4, majority of the respondents are ready to receive and use feedback from their colleagues and pupils in order to improve their teaching and learning process $(\mathrm{M}=3.54, \mathrm{SD}=0.58)$. On the other hand, respondents do score low in their readiness to make detailed preparations before teaching $(\mathrm{M}=3.23$, $\mathrm{SD}=0.63)$.

Table 1. Cronbach's alpha for Section 2 and 3.

\begin{tabular}{ccc}
\hline Section & Construct & Cronbach's alpha $(\boldsymbol{\alpha})$ \\
\hline Section 2 & ESL teachers' knowledge & 0.94 \\
Section 3 & ESL teachers' readiness & 0.86 \\
All & & 0.93
\end{tabular}


Table 2. Total mean score based on section in the survey.

\begin{tabular}{lcc}
\hline \multicolumn{1}{c}{ Section } & MEAN & SD \\
\hline ESL primary school teachers' knowledge on SBA implementation & 3.37 & 0.45 \\
ESL primary school teachers' readiness on SBA implementation & 3.27 & 0.37 \\
\hline
\end{tabular}

Table 3. The highest and lowest mean score for Section 2.

\begin{tabular}{llll}
\hline \multicolumn{1}{c}{$\begin{array}{c}\text { Section 2: ESL primary school teachers' } \\
\text { knowledge on SBA implementation }\end{array}$} & Mean & SD & \\
\hline $\begin{array}{l}\text { I have clear understanding about the Performance Level } \\
\text { descriptors in the Standard-Based Curriculum and } \\
\text { Assessment Document (DSKP) from level 1 to 6. }\end{array}$ & 3.38 & 0.58 & Highest mean score \\
$\begin{array}{l}\text { I know how to use assessment strategies to improve } \\
\text { pupils' higher order thinking skills (HOTS) in SBA. }\end{array}$ & 3.18 & 0.57 & Lowest mean score \\
\hline
\end{tabular}

Table 4. The highest and lowest mean score for Section 3.

\begin{tabular}{llll}
\hline \multicolumn{1}{c}{$\begin{array}{c}\text { Section 3: ESL primary school teachers' } \\
\text { readiness on SBA implementation }\end{array}$} & Mean & SD & \\
\hline $\begin{array}{l}\text { I am ready to receive feedback from colleagues regarding } \\
\text { the implementation of SBA in my class. }\end{array}$ & 3.54 & 0.58 & Highest mean score \\
$\begin{array}{l}\text { I am ready to use feedback from my pupils' achievement } \\
\text { in SBA to improve my quality of teaching and learning. }\end{array}$ & 3.54 & 0.58 & Highest mean score \\
$\begin{array}{l}\text { I am ready to make detailed preparations before teaching } \\
\text { so that teaching takes place smoothly. }\end{array}$ & 3.23 & 0.63 & Lowest mean score \\
\hline
\end{tabular}

\section{Discussion}

\subsection{ESL Teachers' Knowledge and School-Based Assessment (SBA)}

Several studies had found that teachers' knowledge on how to conduct assessment can affect the success of teaching and learning (Veloo et al., 2015). With the implementation of SBA, Malaysian ESL teachers are required to master and able to implement several types of assessments based on the pupils' need. Unfortunately, the demographic findings from this study indicate that only $70 \%$ percent of the respondents had attended any seminar or workshop on SBA throughout their career, this number is quite concerning as by $9^{\text {th }}$ year of SBA implementation, all ESL teachers supposedly had at least have attended seminar or workshop once. Talib et al. (2014), argues that teachers' knowledge on SBA is highly dependent on either they had attended seminars, courses and briefing on SBA. Nevertheless, the finding of this research indicates that majority of the respondents are knowledgeable in regards to SBA in English KSSR. As discussed previously, teachers who had acquired knowledge on SBA are more likely ready to implement the SBA in schools with high percentage of success. In short, when ESL teachers are highly knowledgeable, their level of readiness to implement SBA in English classes is positively high. Additionally, the finding is similar to result of study conducted by Veloo et al. (2015) where Malaysian teachers are 
highly knowledgeable about the SBA in primary classroom.

\subsection{ESL Teachers' Readiness on the Implementation of School-Based Assessment (SBA)}

Correspondingly, the result also shows that ESL teachers' level of readiness in implementing SBA is positively high as well. Unfortunately, the finding indicates that ESL teachers' level of readiness in making detailed preparation before teaching so that teaching takes place smoothly was not as high as the others. As stated by Veloo et al. (2015) this could be due to teachers are having problem to conduct SBA more creatively due to time constraints and inadequate resources. Nevertheless, the result indicate that majority of the respondents have positive attitude in their readiness to receive feedback and use it to improve their teaching and learning process. Therefore, it is a good start for ESL teachers in improving their level of knowledge and readiness in SBA. Additionally Cheah (2010) stated that teachers' attitude is one of the biggest challenges in SBA implementation. Meanwhile, Brown (2004) highlighted the importance on evaluating ESL teachers' perceptions as it could tremendously affect the pupils' outcomes.

Ultimately, findings from this research are in line with the PCK framework by Schulman. Whereby, content and pedagogical knowledge should exist in balance in order for the assessment process to be successful. Meanwhile, although some researchers argue on the effectiveness of the "Cascading Model" by the Ministry of Education in disseminating the transformation of assessment in Malaysian primary schools, findings from this research stated otherwise. The dissemination of the implementation of SBA by the Ministry of Education to ESL teachers was proved to be successful albeit the degree of successfulness is still unknown. Finally, the findings are also in parallel with education reform in Malaysia that assessment should be viewed from wider perspective that is as an integral part of the curriculum towards ensuring pupils to acquire knowledge, skill and values.

\section{Conclusion}

This study aims to investigate ESL teachers' level of knowledge and readiness in regard to SBA implementation in Malaysian assessment system. The results of this study could give relevant current picture on ESL teachers' knowledge and readiness on SBA implementation to educational stakeholders. This study recommends that ESL teachers take initiatives to constantly improve their level of knowledge in regards to SBA in English KSSR as it could highly affect their readiness to implement the SBA in schools. As for further research, this study can be applied to broader aspects of the current primary school curriculum in Malaysia. For example, this study can be conducted on Mathematics teachers or science teachers. Furthermore, the study could be conducted with larger sample size for the result to have greater impact and generalization can be made to a broader population. Finally, it is recommended that this study to be replicated 
with a mixed-method research design to help researchers gain information more extensively on ESL teachers' level of knowledge and readiness on School-based assessment implementation.

\section{Acknowledgements}

This research is funded by University Kebangsaan Malaysia research grant no. GG-2020-027 and GGPM-2019-037

\section{Conflicts of Interest}

The authors declare no conflicts of interest regarding the publication of this paper.

\section{References}

Berry, R. (2011). Assessment Reforms around the World. In Assessment Reform in Education (pp. 89-102). Dordrecht: Springer. https://doi.org/10.1007/978-94-007-0729-0_7

Cheah, U. H. (2010). Assessment in Primary Mathematics Classrooms in Malaysia. Fourth APEC-Tsukuba International Conference: Innovation of Mathematics Teaching and Learning through Lesson Study-Connection between Assessment and Subject Matter, Tokyo, 17-21 February 2010, 1-7.

Cheng, L., Andrews, S., \& Yu, Y. (2011). Impact and Consequences of School-Based Assessment (SBA) Students' and Parents' Views of SBA in Hong Kong. Language Testing, 28, 221-249. https://doi.org/10.1177/0265532210384253

Chew, F. P., \& Muhamad, N. (2017). Readiness of Implementation of School-Based Assessment among the Malay Language Teachers in National Schools. Advanced Science Letters, 23, 2169-2173. https://doi.org/10.1166/asl.2017.8589

Etikan, I., Musa, S. A., \& Alkassim, R. S. (2016). Comparison of Convenience Sampling and Purposive Sampling. American Journal of Theoretical and Applied Statistics, 5, 1-4. https://doi.org/10.11648/j.ajtas.20160501.11

Fook, C. Y., \& Sidhu, G. K. (2006). School-Based Assessment among ESL Teachers in Malaysian Secondary Schools. Jurnal Pendididkan USM, 9, 1-8.

Ghazali, N. H. C. M. (2017). The Implementation of School-Based Assessment System in Malaysia: A Study of Teacher Perceptions. Geografia-Malaysian Journal of Society and Space, 12, 104-107.

Hashim, C. H., Ariffin, A., \& Hashim, N. M. (2013). Ideal vs. Reality: Evidences from Senior Teachers' Experiences on the Malaysian School-Based Assessment System (SBA). Proceedings of the Malaysian Education Deans' Council, Malaysia, n.d, 1-12.

John, M. (2018). Assessment Reform in Malaysia: Policy into Practice in Primary Schools. Stirling: University of Stirling.

Khatab, Z. A. (2012). A Study on English Teachers' Assessment Practices on the School-Based Assessment for English Language. https://www.researchgate.net/publication/291975343

Kiong, T. T., Saien, S., Heong, Y. M., \& Mohamad, M. M. (2017). TRIZ: An Alternate Way to Solve Problem for Student. International Journal of Academic Research in Business and Social Sciences, 7, 2222-6990.

Kumarsir, L. A., \& Shah, P. M. (2020). Teachers Motivation towards Teaching in Rural Indigenous Schools. International Journal of Multidisciplinary Research and Publica- 
tions (IJMRAP), 3, 20-29.

Majid, F. (2011). SBA in Malaysian Schools: The Concern of the English Teachers. Journal of US-China Education Review, 8, 1-15.

Mansor, A. N., Leng, O. H., Rasul, M. S., Raof, R. A., \& Yusoff, N. (2013). The Benefits of School-Based Assessment. Asian Social Science, 9, 101. https://doi.org/10.5539/ass.v9n8p101

McMillan, J. H. (2000). Fundamental Assessment Principles for Teachers and School Administrators. Practical Assessment, Research \& Evaluation, 7, 78-93.

MES Malaysian Examination Syndicate (2012). Panduan Pengurusan Pentaksiran Berasaskan Sekolah (PBS) [Guidelines for School-Based Assessment and Management $(S B A)]$. Kuala Lumpur: Ministry of Education.

Ministry of Education (2010) Dokumen Standard: Bahasa Inggeris Tahun Satu (Performance standards: English Year 1). Putrajaya, Malaysia: Curriculum Development Division, Ministry of Education.

Ministry of Education (2013). Malaysia Education Blueprint 2013-2025 (Preschool to Post Secondary Education). Putrajaya: Ministry of Education.

Othman, I., Salleh, N. M., \& Norani, N. A. M. (2013). The Implementation of School Based Assessment in Primary School Standard Curriculum. International Journal of Education and Research, 1, 1-10.

Raman, K., \& Yamat, H. (2014). English Teachers' Voices on the Challenges of the School-Based Assessment. Frontiers of Language and Teaching, 5, 66-74.

Shulman, L. S. (1987). Knowledge and Teaching: Foundations of the New Reform. Harvard Educational Review, 57, 1-22.

Stiggins, R. (2005). From Formative Assessment to Assessment for Learning: A Path to Success in Standards-Based Schools. Phi Delta Kappan, 87, 324-328.

Talib, R., Naim, H. A., Ali, N. S. M., \& Hassan, M. A. M. (2014). School-Based Assessment: A Study on Teacher's Knowledge and Practices. Fifth International Graduate Conference on Engineering, Humanities and Social Science, Johor Bahru, 19-21 August 2014, 1-7.

Troyan, F. J., Cammarata, L., \& Martel, J. (2017). Integration PCK: Modeling the Knowledge(s) Underlying a World Language Teacher's Implementation of CBI. Foreign Language Annals, 50, 458-476. https://doi.org/10.1111/flan.12266

Ursachi, G., Horodnic, I. A., \& Zait, A. (2015). How Reliable Are Measurement Scales? External Factors with Indirect Influence on Reliability Estimators. Procedia Economics and Finance, 20, 679-686. https://doi.org/10.1016/S2212-5671(15)00123-9

Van Driel, J. H., \& Berry, A. (2012). Teacher Professional Development Focusing on Pedagogical Content Knowledge. Educational Researcher, 41, 26-28.

https://doi.org/10.3102/0013189X11431010

Veloo, A., Krishnasamy, H. N., \& Md-Ali, R. (2015). Teachers' Knowledge and Readiness towards Implementation of School Based Assessment in Secondary Schools. International Education Studies, 8, 193-203. https://doi.org/10.5539/ies.v8n11p193

Yan, Z. (2014). Predicting Teachers' Intentions to Implement School-Based Assessment Using the Theory of Planned Behaviour. Educational Research and Evaluation, 20, 83-97. https://doi.org/10.1080/13803611.2013.877394 